\title{
SMALL POPULATION SIZE OF THE PRIBILOF ROCK SANDPIPER CONFIRMED THROUGH DISTANCE-SAMPLING SURVEYS IN ALASKA
}

\author{
Daniel R. Ruthrauff ${ }^{1,2,4}$, T. Lee Tibbitts ${ }^{1}$, Robert E. Gill Jr. ${ }^{1}$, Maksim N. Dementyev ${ }^{3}$, \\ AND COLleEn M. HANDEL ${ }^{1}$ \\ ${ }^{1}$ Alaska Science Center, U.S. Geological Survey, 4210 University Drive, Anchorage, AK 99508 \\ ${ }^{2}$ Royal Netherlands Institute for Sea Research (NIOZ), P. O. Box 59, 1790 AB Den Burg, Texel, the Netherlands \\ ${ }^{3}$ Vertebrate Zoology Department, Moscow State University, Vorobjovy Gory, 119992 Moscow, Russia
}

\begin{abstract}
The Rock Sandpiper (Calidris ptilocnemis) is endemic to the Bering Sea region and unique among shorebirds in the North Pacific for wintering at high latitudes. The nominate subspecies, the Pribilof Rock Sandpiper (C. p. ptilocnemis), breeds on four isolated islands in the Bering Sea and appears to spend the winter primarily in Cook Inlet, Alaska. We used a stratified systematic sampling design and line-transect method to survey the entire breeding range of this population during springs 2001-2003. Densities were up to four times higher on the uninhabited and more northerly St. Matthew and Hall islands than on St. Paul and St. George islands, which both have small human settlements and introduced reindeer herds. Differences in density, however, appeared to be more related to differences in vegetation than to anthropogenic factors, raising some concern for prospective effects of climate change. We estimated the total population at 19832 birds (95\% CI $17853-21$ 930), ranking it among the smallest of North American shorebird populations. To determine the vulnerability of C. p. ptilocnemis to anthropogenic and stochastic environmental threats, future studies should focus on determining the amount of gene flow among island subpopulations, the full extent of the subspecies' winter range, and the current trajectory of this small population.
\end{abstract}

Key words: Alaska, Bering Sea, Calidris ptilocnemis, conservation, distance sampling, population size, Pribilof Rock Sandpiper.

\section{Tamaño Poblacional Pequeño de Calidris p. ptilocnemis Confirmado por Medio de Estudios de Muestreos de Distancia en Alaska}

Resumen. La especie Calidris ptilocnemis es endémica de la región del Mar de Bering y única entre las aves playeras en el Pacífico del Norte por invernar a altas latitudes. La subespecie nominada, C. p. ptilocnemis, cría en cuatro islas aisladas del Mar de Bering y parece pasar el invierno principalmente en Cook Inlet, Alaska. Empleamos un diseño de muestreo sistemático estratificado y un método de líneas de transectas para estudiar todo el rango de cría de esta población durante las primaveras de 2001 al 2003. Las densidades fueron hasta cuatro veces más altas en las islas St. Matthew y Hall, deshabitadas y ubicadas más al norte, que en las islas St. Paul y St. George, las cuales tienen pequeños asentamientos humanos y rebaños de renos introducidos. Las diferencias en densidad, sin embargo, parecen estar más relacionadas a diferencias en la vegetación que a factores antropogénicos, creando preocupación sobre los futuros efectos del cambio climático. Estimamos la población total en 19832 aves (95\% IC 17 853-21 930), ubicándose entre las poblaciones más pequeñas de aves playeras de América del Norte. Para determinar la vulnerabilidad de C. p. ptilocnemis a las amenazas antropogénicas y estocásticas del ambiente, los futuros estudios deberían enfocarse en determinar la cantidad de flujo génico entre las subpoblaciones de las islas, la extensión total del rango invernal de la subespecie y la trayectoria actual de esta pequeña población.

\section{INTRODUCTION}

The Rock Sandpiper (Calidris ptilocnemis) is the only polytypic bird species endemic to Beringia (Pruett and Winker 2005), with all four subspecies breeding in coastal habitats ringing the Bering Sea (Gill et al. 2002). It is among the least migratory of all calidridine sandpipers and remains at high latitudes throughout its annual cycle (Gill et al. 2002). The nominate form, C. p. ptilocnemis (Coues, 1873), was considered a distinct species by Ridgway (1919) and originally named the "Pribilof Sandpiper" from the location of the type specimen. Its current taxonomic position has been confirmed originally on the basis of plumage and morphology (Conover 1944) and more recently by genetic analyses (Pruett and Winker 2005).

The core breeding range of the Pribilof Rock Sandpiper (hereafter Pribilof Sandpiper) seems certain. As summarized by Conover (1944), the Pribilof Sandpiper nests primarily on four Bering Sea islands (St. Paul, St. George [together the

Manuscript received 15 July 2011; accepted 13 December 2011.

${ }^{4}$ E-mail: druthrauff@usgs.gov

The Condor, Vol. 114, Number 3, pages 544-551. ISSN 0010-5422, electronic ISSN 1938-5422. @ 2012 by The Cooper Ornithological Society. All rights reserved. Please direct all requests for permission to photocopy or reproduce article content through the University of California Press's Rights and Permissions website, http://www.ucpressjournals.com/ reprintInfo.asp. DOI: 10.1525/cond.2012.110109 


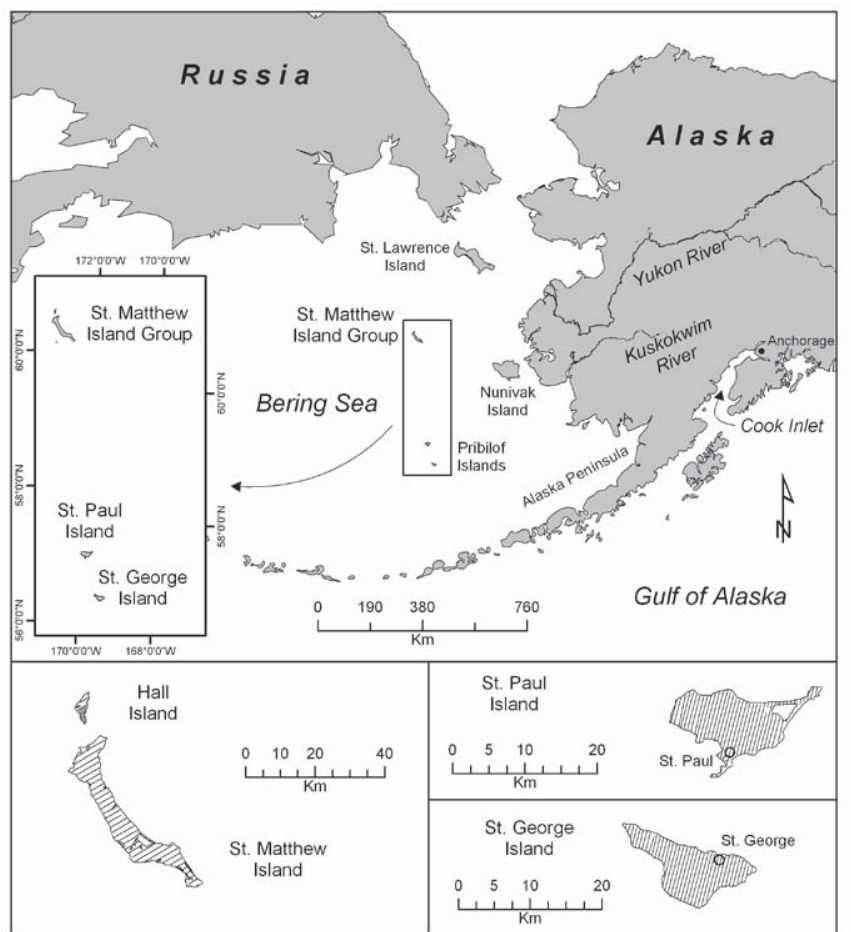

FIGURE 1. The Bering Sea region showing the breeding range of the Pribilof Rock Sandpiper, Calidris p. ptilocnemis (inset boxes, upper panel), and the layout of transects on each island (lower panels). Additional site names refer to locations mentioned in the text.

Pribilof Islands], St. Matthew, and Hall; Fig. 1). Questions remain as to whether it also breeds on two other nearby Bering Sea islands (Nunivak and St. Lawrence, Fig. 1; see Gill et al. 2002), but Conover (1944) and Gibson and Kessel (1997) concluded that the Rock Sandpipers at these two locations belong to the subspecies C. p. tschuktschorum. For this study we followed these conclusions and consider the breeding range of the Pribilof Sandpiper as shown in Fig. 1.

The winter range of the Rock Sandpiper in North America extends from the coasts of the Aleutian Islands and Gulf of Alaska and south to northern California (in Gill et al. 2002), but the ranges of each subspecies are poorly described. Among the four subspecies of the Rock Sandpiper, the Pribilof Sandpiper is the only one with a distinctive basic plumage (Conover 1944, Gill et al. 2002), enabling easy discrimination from the three other subspecies. There are several reports (Gill and Tibbitts 1999, in Gill et al. 2002) of large numbers of Rock Sandpipers from the Gulf of Alaska in winter, but none mentions subspecies. Erikson (1977) reported about 3400 birds in early February in Cook Inlet, Alaska. Small numbers of Rock Sandpipers were subsequently reported through the early 1990s (Gill and Tibbitts 1999) from both upper and lower Cook Inlet in winter, but not until specimens were collected in upper Cook Inlet in February 1997 was it determined that these included Pribilof Sandpipers (Daniel Gibson, pers. comm.; Gill, unpubl. data). Recent field work in lower Cook Inlet in winter has revealed a mixture of subspecies, most a darker form (likely C. p. tschuktschorum) but also including some Pribilof Sandpipers (Ruthrauff, unpubl. data). Concurrent aerial and ground surveys of upper Cook Inlet in winter have revealed many thousands of Rock Sandpipers, almost all of the Pribilof subspecies (Gill and Tibbitts 1999; Gill and Ruthrauff, unpubl. data). Given the subspecies' extremely limited breeding range, the paucity of winter records elsewhere, and the large number of birds recorded in upper Cook Inlet through most winters, we hypothesized that this area hosts the majority of the Pribilof Sandpiper's population during winter (Gill and Tibbitts 1999, Gill et al. 2002).

Small, geographically restricted populations are inherently more vulnerable to population-level perturbations (Pimm et al. 1988, Davidson et al. 2009). As such, the Rock Sandpiper is one of only three North American shorebird species included on the "Red List" of global conservation concern by National Audubon Society's WatchList program (Butcher et al. 2007). For similar reasons, the Pribilof Sandpiper has been designated as a subspecies of high conservation concern in both the U.S. Shorebird Conservation Plan (Brown et al. 2001) and the Alaska Shorebird Conservation Plan (Alaska Shorebird Group 2008). Effective conservation of any wildlife population requires an understanding of its population trajectory, and an accurate estimate of population size provides a baseline against which change may be measured. On the basis of winter counts in Cook Inlet, Gill and Tibbitts (1999) and Gill et al. (2002) estimated the Pribilof Sandpiper's population at $20000-25000$ individuals. Despite uncertainty about the subspecific composition of the Rock Sandpipers wintering in Cook Inlet (Gill et al. 2002), this figure has been employed for conservation planning (Morrison et al. 2006, Alaska Shorebird Group 2008).

To address uncertainties about the subspecies' population size, we designed and implemented a survey across its breeding range to obtain an accurate, baseline population estimate. The four remote and rugged islands that encompass the breeding area differ in size, latitude, and terrain and also have varied histories of habitation by humans and introduced reindeer (Rangifer tarandus). Thus our study represents a rare opportunity not only to systematically survey a bird population of conservation concern across its entire breeding range but also to investigate variation in its density with respect to anthropogenic and environmental factors.

\section{METHODS}

\section{STUDY AREAS}

We surveyed each island in the Bering Sea where the Pribilof Sandpiper breeds: St. Paul $\left(109 \mathrm{~km}^{2}\right)$ and St. George (90 $\left.\mathrm{km}^{2}\right)$, and the more northerly St. Matthew $\left(314 \mathrm{~km}^{2}\right)$ and Hall $\left(16 \mathrm{~km}^{2}\right)$ islands (Fig. 1). All islands are either wholly or 
partially included within the Alaska Maritime National Wildlife Refuge, managed by the U.S. Fish and Wildlife Service. The Pribilof Islands support two villages with populations of 437 and 125 on St. Paul and St. George, respectively (U.S. Census Bureau 2011); St. Matthew and Hall islands are uninhabited. All four islands are characterized by rocky shorelines, massive sea cliffs, and gently rolling terrain topped by rocky uplands. St. Paul has the lowest mean elevation ( $38 \mathrm{~m}$ ), followed by St. Matthew (94 m), St. George (102 m), and Hall (182 m); maximum elevations range from $201 \mathrm{~m}$ on St. Paul to $507 \mathrm{~m}$ on Hall. Predominant habitats on all islands include low-lying meadows, dwarf-shrub heath tundra dominated by Empetrum nigrum, thick lichen mats, and sparsely vegetated rocky uplands (Preble and McAtee 1923, Rausch and Rausch 1968, Byrd and Norvell 1993, Talbot et al. 2001). The more southerly Pribilof Islands also contain extensive regions of forb tundra dominated by Lupinus nootkatensis and Angelica lucida.

Introduced ungulates can greatly alter vegetation cover (Klein 1987), and these Bering Sea islands have varied histories of large-mammal introductions. Reindeer were introduced to the Pribilof Islands in 1911 as an additional food source for the islands' residents (Osgood et al. 1915), and the size of each herd has fluctuated greatly since introduction (Swanson and Barker 1992). Reindeer were introduced to St. Matthew Island in 1944, but the population collapsed 20 years later following years of near-exponential population growth (Klein 1968); the last reindeer died there in the early 1980s (Klein 1987). Reindeer have never been introduced to Hall Island.

\section{SURVEY DESIGN}

We conducted line-transect surveys (Buckland et al. 2001) to estimate the breeding densities and population size of the Pribilof Sandpiper. Gill et al. (2002) suggested that all individuals of the subspecies, including nonbreeders, reside on these islands during the breeding season. We designed the surveys to assure that all critical assumptions of distance sampling (Buckland et al. 2001) were met: (1) transect lines were placed randomly relative to the distribution of the birds, (2) birds directly on the transect line were always detected, (3) birds were detected at their initial location, prior to any movement in response to the observer, and (4) distances to the birds were measured accurately. Using a randomly chosen start, we selected a systematic sample of line transects parallel to the short axis of each island. This design facilitated access via the coast and ensured transect lengths $(<10 \mathrm{~km})$ that could reasonably be surveyed by foot in a day. We spaced transects at $0.5-\mathrm{km}$ intervals on St. Paul $(n=38)$, St. George $(n=39)$, and Hall $(n=15)$ islands and at $1.5-\mathrm{km}$ intervals on the much larger St. Matthew Island $(n=35$; Fig. 1). On Hall Island three transects were not surveyed and two others were only partially completed because of time constraints; on St. Matthew one transect was not surveyed because of dangerous terrain. We did not survey sections of transects that crossed large lakes $\left(\geq 1 \mathrm{~km}^{2}\right)$, and we excluded these areas from density calculations. Large lakes excluded $\left(18.7 \mathrm{~km}^{2}\right)$, the breeding range totaled $510.5 \mathrm{~km}^{2}$.

We timed our surveys in each area to coincide with the establishment and maintenance of breeding territories, a period during which breeding pairs (and males in particular) are very active and highly detectable (Gill et al. 2002). During this period the males engage in conspicuous flight displays and give an array of distinctive, context-specific vocalizations. We surveyed St. Paul from 1 to 19 May 2001, St. George from 4 to 16 May 2002, St. Matthew from 29 May to 29 June 2003, and Hall on 21 June 2003. Surveys at St. Matthew and Hall took place 3-4 weeks later than at the Pribilof Islands to coincide with the delayed breeding season at these higher-latitude sites. We believe interannual movement of individuals between islands to be minimal because studies of C. p. tschuktschorum have shown the birds to be strongly site-faithful (Tomkovich 1994, Johnson et al. 2009). Thus we assumed that each island's survey represented an independent sample.

The probability of detection of shorebirds nesting in the subarctic, unlike that of passerines, varies little through the day (Nebel and McCaffery 2003), so to maximize sampling we surveyed throughout daylight. We surveyed only when conditions were suitable (i.e., wind $<25 \mathrm{~km} \mathrm{hr}^{-1},>500 \mathrm{~m}$ visibility, no precipitation); if they deteriorated during a survey, we repeated it when conditions improved and discarded the original results. A total of eight observers participated, one in all three years, three in two years, and four in only one of the years. We assigned observers randomly to the transects surveyed each season. Prior to field work, observers were trained in distance estimation and in recognition and interpretation of Pribilof Sandpiper behavior and vocalizations. In a complementary study, observers on St. Matthew and Hall simultaneously surveyed for McKay's Bunting (Plectrophenax hyperboreus) (Matsuoka and Johnson 2008).

Observers used a GPS to locate each transect's starting point and to navigate to the end point on the opposite shore. Observers used a laser rangefinder to measure the perpendicular distance from the transect line to the initial location of each bird seen (or flock center for $\geq 2$ birds). For birds heard but not seen, observers used the rangefinder to estimate the distance to the approximate location of the bird. There were 184 aural-only detections (9.3\% of total) of birds whose distances were estimated in this way. Observers recorded flock size for each detection and any behavior or vocalizations that would help determine a bird's sex and status (territorial or transient). The Pribilof Sandpiper is sexually dimorphic (Gill et al. 2002), but differences in size and plumage are subtle and not easily discerned at a distance. Therefore, in addition to morphological cues, observers relied on sex-specific behaviors (e.g., the male's flight displays and nest-scraping behaviors) and vocalizations (e.g., the male's songs, "cricket" calls, rhythmically repeated calls; Miller et al. 1988, Gill et al. 2002) to determine the bird's sex. 


\section{STATISTICAL ANALYSES}

The brevity of our visit to each island and our need to survey whenever weather permitted constrained our ability to randomize surveys by time of season and time of day. In a post-hoc assessment of potential temporal effects on detection probability, we calculated the number of birds detected per linear kilometer and evaluated transects on each island for evidence of seasonal (except Hall Island, surveyed on one day) and diurnal trends in detection rates. The number of detections per kilometer did not vary by date (linear regression; all islands $P>0.05$ ) or by the time of the survey's start $(<12: 00 \mathrm{hr}$ AST, 12:01-16:00 hr, $>16: 00 \mathrm{hr}$; ANCOVA, $P=0.62$ ). Therefore, we excluded season and time of day as covariates in our subsequent modeling.

We used the Multiple Covariates Distance Sampling (MCDS) engine in program Distance 6.0, release 2 (Thomas et al. 2010), to model the potential effects of sex, island, and island group on detection probability. We defined sex (male, female, or unknown) according to the sex-specific aural, visual, and behavioral cues that we used to detect each individual or group. For instance, if we first detected a male aurally by its malespecific vocalization and subsequently observed it interacting with a bird identified as a female by bill morphology and plumage, we recorded the presumed sex of both birds in the field (male and female, respectively). In analysis of detection probability, however, we coded both birds as male-type detections. We included the four individual islands as covariates in order to account for island-specific factors related to survey design (e.g., year, observers, seasonal timing) and physiography (e.g., general habitat, elevation). In an alternative set of models we included a covariate for island group (Pribilofs vs. St. Matthew and Hall) to test for latitudinal effects on detection probability and potential influences of increased survey duties at Hall and St. Matthew, where observers simultaneously surveyed for McKay's Bunting. Although some studies have shown that cluster size can affect detection probability (Drummer and McDonald 1987, Marques and Buckland 2003), we did not include it as a covariate because only $2 \%$ of the birds were detected in groups larger than two.
Our initial step in the analysis was to assess the data for the best truncation distance $(150 \mathrm{~m})$ and intervals for pooling (equal intervals of $10 \mathrm{~m}$ ) to improve the models' fit (Buckland et al. 2001). We excluded all observations of birds in straight-line overflight (i.e., transient birds passing through the survey area) to minimize positive bias in density estimates arising from movement of birds. Using this reduced data set, we assessed the fit of hazard-rate and half-normal key detection functions with and without series-adjustment terms (cosine and simple polynomial for hazard-rate, cosine and hermite polynomial for half-normal; Buckland et al. 2001). Our candidate set included 12 models, 6 for each detection function: (1) no covariates, (2) sex, (3) island, (4) island group, (5) sex + island, and (6) sex + island group. We did not include island and island group in the same models because of their redundancy, and we did not include any interactions because we expected the effect of sex-specific behaviors on detection probability to be consistent across the breeding range. We used Akaike's information criterion adjusted for small sample sizes (AIC $\left.{ }_{c}\right)$ and Akaike weights $\left(w_{i}\right)$ to assess the relative support for each of the candidate models considered (Burnham and Anderson 2002). We classified the four islands as separate strata and calculated point estimates of density and population size for each, along with associated bootstrap-generated $95 \%$ confidence intervals (Buckland et al. 2001). We weighted these by each island's area (determined with ArcGIS 9.2 at mean sea level) to estimate overall density and population size.

\section{RESULTS}

We detected a total of 2376 Pribilof Rock Sandpipers in 1967 groups on 123 transects encompassing $575.9 \mathrm{~km}$ across the four Bering Sea islands on which they breed (Fig. 1, Table 1). The truncated sample used for estimation of densities included 2114 sandpipers in 1738 groups. Mean group size was $1.22 \pm 0.01$ (SE) birds; almost all birds were detected as singles (86\%) or in groups of two (12\%), and the largest group was of six birds.

TABLE 1. Density and estimated size of the populations of the Pribilof Rock Sandpiper by island relative to area, sampling effort, and number of individuals detected within each stratum during line-transect surveys across the subspecies' entire breeding range in Alaska, 2001-2003. Stratified point estimates and bootstrap-generated 95\% confidence intervals (CI) are based on the best-fitting model (halfnormal detection function with two-term cosine adjustment fitting the covariates sex and island group; see Table 2). Areas of large lakes were excluded from surveys and calculations of density; birds detected $>150 \mathrm{~m}$ from the observers were truncated during the analysis (see Methods).

\begin{tabular}{|c|c|c|c|c|c|c|c|c|}
\hline \multirow[b]{2}{*}{ Island } & \multirow[b]{2}{*}{ Area $\left(\mathrm{km}^{2}\right)$} & \multicolumn{2}{|c|}{ Transects } & \multirow[b]{2}{*}{ Individuals detected } & \multicolumn{2}{|c|}{ Density (birds km²) } & \multicolumn{2}{|c|}{ Population size } \\
\hline & & $n$ & $\mathrm{~km}$ & & Mean & $95 \% \mathrm{CI}$ & Estimate & $95 \% \mathrm{CI}$ \\
\hline St. Paul & 109 & 38 & 205.1 & 396 & 11.78 & $9.50-14.11$ & 1226 & $988-1469$ \\
\hline St. George & 90 & 39 & 170.6 & 770 & 29.08 & $24.05-33.71$ & 2607 & $2155-3022$ \\
\hline St. Matthew & 314 & 34 & 180.5 & 1104 & 50.82 & $44.83-57.50$ & 15280 & $13480-17289$ \\
\hline Hall & 16 & 12 & 19.8 & 106 & 44.73 & $34.14-57.70$ & 719 & 549-928 \\
\hline Combined & 529 & 123 & 575.9 & 2376 & 38.83 & $34.97-42.96$ & 19832 & $17853-21930$ \\
\hline
\end{tabular}


Using a combination of cues, observers identified 940 sandpipers as males ( $45 \%$ of total), 321 as females (15\%), 364 associating as breeding pairs (17\%), and the remaining 489 as individuals of unknown sex $(23 \%)$. Across all four islands, the effective strip half-width was $60.6 \mathrm{~m}$ (95\% confidence interval $58.3-$ 63.0), indicating that we surveyed an effective area of about $70 \mathrm{~km}^{2}$, or $14 \%$ of the total breeding range.

Our model-selection process for detection probability yielded strong support $\left(w_{i}=0.85\right)$ for a single model over the other 11 in the candidate set; this model included sex and island group as covariates and fit a half-normal key function with a two-term cosine series adjustment (Table 2, Fig. 2; $\left.\mathrm{AIC}_{c}=8582.1\right)$. The second-ranked model carried the remainder of the weight $\left(w_{i}=0.15, \Delta \mathrm{AIC}_{c}=3.42\right)$ and differed from the top model only in that it fit individual islands as covariates instead of island group. These models yielded nearly identical values for the estimates of the sex covariate, so we did not average models and hereafter present only the results of the best-supported model. Detection probability was lowest for female-type detections, declining rapidly and steadily with distance from the observer, and was marginally higher for male-type detections than for birds of unknown sex (Fig. 2). Detection probability was higher on the Pribilof Islands than on St. Matthew and Hall islands (Table 2).

Of the four islands, St. Matthew supported the highest density (50.82 birds km$~^{-2}$ ) and greatest number (15 280) of sandpipers; density on the nearby but much smaller Hall Island was similar (Table 1). Although almost equal in size to its neighbor St. Paul Island, St. George supported over twice as many sandpipers (2607 birds) as St. Paul (1226 birds), and densities on St. Paul (11.78 birds km${ }^{-2}$ ) were only a quarter of those on St. Matthew (Table 1). Across the entire breeding range, Pribilof Sandpipers occurred at an average density of 38.85 birds km$~^{-2}$, yielding an overall population estimate of 19832 birds ( $95 \%$ confidence interval 17 853-21 930; Table 1).

TABLE 2. Coefficients of the best-supported model for probability of detection of the Pribilof Rock Sandpiper, which included covariates for sex (female, male, and unknown [reference level]) and island group (Pribilof Islands vs. St. Matthew and Hall islands [reference level]). Data are from line-transect surveys from 2001-2003 on the four islands constituting the subspecies' breeding range. The data were best fit by a half-normal key function with a two-term cosine series adjustment; the log likelihood of this model was -4285.04 .

\begin{tabular}{lr}
\hline \hline Parameter & Estimate \pm SE \\
\hline Scale parameter & $68.75 \pm 1.30$ \\
Female & $-0.65 \pm 0.09$ \\
Male & $0.04 \pm 0.09$ \\
Pribilof Islands & $0.26 \pm 0.05$ \\
Second-order adjustment term & $0.25 \pm 0.04$ \\
Third-order adjustment term & $0.11 \pm 0.04$ \\
\hline
\end{tabular}

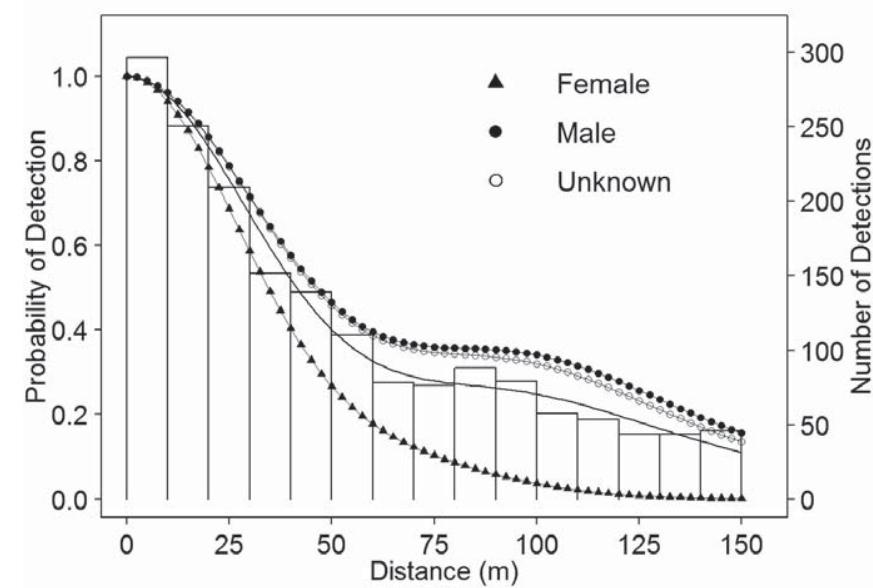

FIGURE 2. Probability of detection of the Pribilof Rock Sandpiper by sex-related behavior (female, male, and unknown sex) relative to distance from the transect line. Marginal-detection curves are derived from the output of the model in Table 2 and control for the effect of island-specific variation in probability of detection. Histogram represents actual survey detections (scale on right axis) binned by $10-\mathrm{m}$ intervals; the solid line without symbols represents the overall fitted detection function.

\section{DISCUSSION}

Our population estimate of about 20000 birds places the Pribilof subspecies of the Rock Sandpiper among the smallest $25 \%$ of the 70 North American shorebird populations treated by Morrison et al. (2006). Although relatively small by these standards, this population size is not necessarily small in the context of population viability, where minimum populations of 2000-7000 animals are considered essential to ensure persistence (see summary in Reed et al. 2003). Small populations are subject to decreased genetic diversity, lower fitness, and increased susceptibility to environmental perturbations (Shaffer 1981, Lande 1993, Reed and Frankham 2003). If gene flow among the island subpopulations is limited, the effective population size of the Pribilof Sandpiper may be smaller than 20000 , and the subspecies may be vulnerable to some of these factors. Almost $80 \%$ of the population breeds on one (St. Matthew) of the four islands on which the subspecies breeds, and each of the other three islands hosts fewer than 3000 individuals. We do not know the extent of interchange between the four islands, and evidence of genetic mixing between Rock Sandpiper subspecies is inconclusive (Pruett and Winker 2005). Given these uncertainties, the high site fidelity of $C . p$. tschuktschorum documented by both Tomkovich (1994) and Johnson et al. (2009) suggests gene flow between and within the four subspecies is limited. Additional genetic analyses of birds from adjacent areas of potential breeding would help resolve uncertainties about any gene flow outside the known range of the Pribilof Sandpiper.

The Pribilof Sandpiper's breeding distribution surely ranks as one of the most restricted among those of any North American shorebird, and its concentration on four small 
islands totaling less than $530 \mathrm{~km}^{2}$ renders the subspecies vulnerable to local and stochastic effects. The marked difference in population density between the Pribilof Islands and the more northerly St. Matthew and Hall islands may indicate such local effects, but without definitive historical data we can only speculate about the factors responsible. St. Matthew and Hall islands have never been inhabited, but permanent human settlements were established on the Pribilof Islands in the late 1700s (Osgood et al. 1915). Historically, residents of the Pribilof Islands hunted Pribilof Sandpipers heavily (Osgood et al. 1915), but hunting pressure has been negligible since the early 1900s (Hanna 1921). The current footprint of human infrastructure is small on both St. Paul and St. George, and vegetation cover on both islands at the time of our study appeared largely unaffected by human habitation.

A further distinction between the two island groups that may have contributed to the difference in population density is the history of reindeer introductions. The Pribilof Islands support the only reindeer herds remaining in the sandpiper's breeding range. Large ungulates may reduce reproduction and recruitment of ground-nesting birds directly through trampling of nests (Wright 1979) and consumption of eggs (Abraham et al. 1977) or indirectly through habitat alteration (Klein 1987). Rock Sandpipers typically nest in dry upland tundra dominated by lichens and ericaceous shrubs (Gill et al. 2002), and excessive reindeer grazing tends to promote graminoids and mosses at the expense of lichen-dominated upland habitats (Klein 1987). Swanson and Barker (1992) attributed much of the fluctuation in reindeer populations on the Pribilof Islands to range degradation, and habitat alteration may account, at least in part, for the difference in the sandpiper's density between the Pribilofs and the currently reindeer-free St. Matthew and Hall islands. It should be noted, however, that anecdotal observations (Hanna 1921, Preble and McAtee 1923) made shortly after reindeer were introduced on the Pribilof Islands in 1911 suggest that during the early 20th century relative densities of sandpipers breeding on the four islands were similar to those we documented: lowest on St. Paul, higher on St. George, and highest on St. Matthew. It is unlikely that the small reindeer populations present then ( 25 on St. Paul and 15 on St. George; Osgood et al. 1915) had yet adversely affected the islands' habitats.

Differences due to a combination of the islands' physiography and latitude may have a greater effect on vegetation cover than do either direct anthropogenic or reindeer-induced effects. The Pribilof Islands are about $425 \mathrm{~km}$ south of Hall and St. Matthew islands, and the mean elevation of St. Paul is considerably lower than that of the other islands ( $38 \mathrm{~m}$, compared to 94-182 m). Concomitantly, on St. Paul the cover of graminoids is greater and the dry upland tundra Pribilof Sandpipers prefer for nesting is less extensive (Tibbitts, unpubl. data). Accurate land-cover maps and more detailed information on the Pribilof Sandpiper's habitat preferences would help clarify the relative contributions of physiography, latitude, human settlement, and reindeer introductions on the sandpiper's population densities on the four islands. Given that our results concur with historical observations (see above), we believe that variation in vegetation types is the most likely cause of island-specific variation in the density of breeding Pribilof Sandpipers.

Understanding the relationship between reproductive success and microhabitat structure would help elucidate potential effects of climate-mediated changes on this small population. There is strong evidence that the marine ecosystem of the Bering Sea region has already experienced a major shift of climatic regime (Hare and Mantua 2000). Studies elsewhere in Alaska have documented how the structure of terrestrial vegetation has been changing dramatically in response to climatic change (Sturm et al. 2001, Hinzman et al. 2005, Tape et al. 2006), with a general trend toward increasing herbaceous and shrub cover and decreasing dwarf shrub/upland tundra habitats. There is no information on how vegetation might be changing on the four Bering Sea islands where the Pribilof Sandpiper breeds, but climate models predict relatively rapid and extensive habitat alteration across high latitudes (Rupp et al. 2000, Euskirchen et al. 2009), changes that may alter current habitat structures throughout the Pribilof Sandpiper's range.

With an accurate baseline for the size of this vulnerable population now established, focus should now turn to determining its trajectory. Our point estimate for the Pribilof Sandpiper's population was similar to the previous approximation of 20 000-25 000 (Gill et al. 2002). This figure was based primarily on winter surveys of upper Cook Inlet, which employed photography to verify counts of large flocks and a partial correction factor based on observer bias in estimating flock size (Gill and Ruthrauff, unpubl. data). Uncertainty remains, however, about what proportion of the population winters in the region surveyed. Surveys of the entire breeding range have greater inferential power than potentially incomplete surveys of the wintering grounds but ground surveys of the breeding range are costly and logistically difficult. Winter surveys may serve as a relatively inexpensive population-monitoring tool once the winter range of the subspecies has been refined. Similarly, if Pribilof Sandpipers are confirmed breeding on Nunivak and St. Lawrence islands, future studies will need to identify the extent of breeding on these islands and integrate counts from these sites into a revised population estimate.

Our findings confirm the need for accounting for differences in detection probability during bird surveys, as has been found in many other studies (see Thompson 2002 for review). As expected, our analysis indicated strong sex-specific differences in detection probabilities, an important consideration when shorebird surveys are designed and their results are analyzed. We found that the probability of detection was considerably higher through male-specific than through female-specific behaviors, which is consistent with the species' breeding ecology (see Study Design). The similarity of detection-probability curves for males and birds of unknown sex suggested a preponderance of males in the latter category. 
Why detection probability varied by island group is less clear. The probabilities of detection were lower on Hall and St. Matthew islands than on the Pribilof Islands, and this trend persisted whether the islands were grouped by latitude or assessed individually. There are no obvious differences between the islands in factors that commonly influence detection probability. For instance, it is unlikely that islandspecific habitats affected the detection process because all of the islands support relatively simple, prostrate vegetation structures. Similarly, two of five observers surveyed both the Pribilof Islands and Hall and St. Matthew islands, making it unlikely that a systematic difference in observer skill accounted for these discrepancies. A systematic difference in bird behavior, however, is a potential cause of the lower probabilities of detection at Hall and St. Matthew. We intentionally surveyed Hall and St. Matthew 2 to 5 weeks later than we did the Pribilof Islands to account for later breeding at the more northerly sites, but there is evidence that we sampled sites at different stages of the breeding cycle and that birds on Hall and St. Matthew had progressed further in the breeding cycle than had birds on the Pribilof Islands. On the Pribilofs, $41 \%$ of all detections were of singing males, compared with $32 \%$ on St. Matthew and Hall. Similarly, $22 \%$ of birds detected on the Pribilofs were in flight display, compared with $9 \%$ of birds on St. Matthew and Hall. Males behaving so conspicuously were detectable at greater distances and likely contributed to increased detection probability on the Pribilof Islands.

Interestingly, detection probabilities were inversely related to bird density. Observers on St. Matthew and Hall islands may have been "swamped" by sandpipers at close distances at the expense of detecting those at greater distances. Simultaneous surveys for McKay's Bunting on St. Matthew and Hall may have further exacerbated this effect, resulting in a probability of detection less than that on the Pribilof Islands. During this effort, the density of McKay's Bunting was estimated at 95.7 birds km$~^{-2}$ (Matsuoka and Johnson 2008), nearly double that estimated for the Pribilof Sandpiper at these sites. Thus a combination of differences in breeding phenology, birds' higher densities, and observers' increased duties likely accounted for the lower probability of detection at these sites than on the Pribilof Islands. It should be noted, however, that analysis of distance-sampling data accounts for such differences in detection probabilities and that estimates of density on the different islands are robust to such variation, provided the assumption of perfect detection on the transect line itself is met (Buckland et al. 2001).

Many migratory birds have a restricted distribution during one phase of their annual cycle, but those with yearround restricted distributions face increased threats (IUCN 2011). Our population estimate from the Pribilof Sandpiper's breeding range serves as an effective foundation upon which its trajectory can be monitored and future research can be established. Because the Pribilof Sandpiper's population is effectively a geographically closed system, it provides researchers the opportunity to take practical action toward conservation. Specifically, we recommend detailed comparative and experimental studies of the effects of habitat structure on reproductive success and recruitment across the breeding range to help elucidate current and past potential anthropogenic and reindeer-induced effects, as well as projected effects of climate change. Additionally, genetic samples that fill geographic gaps identified by Pruett and Winker (2005), along with measures of adult survival and inter-island movements, would enable a more complete assessment of metapopulation dynamics and vulnerability to stochastic factors.

\section{ACKNOWLEDGMENTS}

For assistance and companionship in the field, we thank Jim Johnson, Mike Litzow, Steve Matsuoka, and Pavel Tomkovich. We thank the crews of the M/V Rolfy and the R/V Alpha Helix for transporting us safely to and from St. Matthew Island, and the staff of the Alaska Maritime National Wildlife Refuge for logistical and financial support throughout the project. Karin Holser offered valuable logistical support on the Pribilof Islands, and the National Marine Fisheries Service provided housing on St. Paul. We especially thank Tanadgusix Corporation (St. Paul) and Tanaq Corporation (St. George) for allowing us access to their lands. Steve Matsuoka assisted with the analysis, and Melissa Cady, Theunis Piersma, Caroline Van Hemert, and two anonymous reviewers provided insightful comments on the manuscript. Any use of trade, product, or firm names is for descriptive purposes only and does not imply endorsement by the U.S. government.

\section{LITERATURE CITED}

Abraham, K. F., P. Mineau, and F. Cooke. 1977. Unusual predators of Snow Goose eggs. Canadian Field-Naturalist 91:317-318.

Alaska Shorebird Group [ONLINE]. 2008. Alaska shorebird conservation plan. Version II. Alaska Shorebird Group, Anchorage, AK. <http://alaska.fws.gov/mbsp/mbm/shorebirds/plans.htm> (15 October 2011).

Brown, S., C. Hickey, B. Harrington, and R. Gill [eds.]. 2001. The U.S. shorebird conservation plan, 2nd ed. Manomet Center for Conservation Sciences. Manomet, MA.

Buckland, S. T., D. R. Anderson, K. P. Burnham, J. L. LaAke, D. L. Borchers, AND L. ThOMAS. 2001. Introduction to distance sampling: estimating abundance of biological populations. Oxford University Press, Oxford, UK.

Burnham, K. P., And D. R. Anderson. 2002. Model selection and multimodel inference: a practical information-theoretic approach, 2nd ed. Springer, New York.

Butcher, G. S., D. K. Niven, A. O. Panjabi, D. N. Pashley, and K. V. Rosenberg. 2007. The 2007 WatchList for United States birds. American Birds 61:18-25.

Byrd, G. V., AND N. Norvell. 1993. Status of the Pribilof Shrew based on summer distribution and habitat use. Northwestern Naturalist 74:49-54.

Conover, H. B. 1944. The North Pacific allies of the Purple Sandpiper. Field Museum of Natural History Zoological Series 29:169-179. 
Davidson, A. D., M. J. Hamilton, A. G. Boyer, J. H. Brown, And G. Ceballos. 2009. Multiple ecological pathways to extinction in mammals. Proceedings of the National Academy of Sciences USA 106:10702-10705.

Drummer, T. D., AND L. L. McDonald. 1987. Size bias in line transect sampling. Biometrics 43:13-21.

ERIKSON, D. 1977. Distribution, abundance, migration, and breeding locations of marine birds, lower Cook Inlet, Alaska, 1976. In L. L. Trasky, L. B. Flagg, and D. C. Burbank [EDS.], Environmental studies of Kachemak Bay and lower Cook Inlet. Unpublished report to Alaska Department of Fish and Game, available at http://www.arlis.org.

Euskirchen, E. S., A. D. McGuire, F. S. Chapin III, S. Yi, AND C. C. ThOMPSON. 2009. Changes in vegetation in northern Alaska under scenarios of climate change, 2003-2010: implications for climate feedbacks. Ecological Applications 19:1022-1043.

Gibson, D. D., AND B. Kessel. 1997. Inventory of the species and subspecies of Alaska birds. Western Birds 28:45-95.

Gill, R. E. JR., AND T. L. TibBitTs. 1999. Seasonal shorebird use of intertidal habitats in Cook Inlet, Alaska. Final report, U.S. Department of the Interior, U.S. Geological Survey, Biological Resources Division and OCS Study, MMS 99-0012, available at http://www.arlis.org.

Gill, R. E., P. S. Tomkovich, And B. J. McCAFfery. 2002. Rock Sandpiper (Calidris ptilocnemis), no. 686. In A. Poole and F. Gill [EDS.], The birds of North America. Birds of North America, Inc., Philadelphia.

Hanna, G. D. 1921. The Pribilof Sandpiper. Condor 23:50-57.

Hare, S. R., And N. J. Mantua. 2000. Empirical evidence for North Pacific regime shifts in 1977 and 1989. Progress in Oceanography 47:103-145.

Hinzman, L. D., N. D. Bettez, W. R. Bolton, F. S. Chapin, M. B. Dyurgerov, C. L. Fastie, B. Griffith, R. D. Hollister, A. Hope, H. P. Huntington, A. M. Jensen, G. J. JiA, T. Jorgenson, D. L. Kane, D. R. Klein, G. Kofinas, A. H. Lynch, A. H. Lloyd, A. D. McGuire, F. E. Nelson, W. C. Oechel, T. E. Osterkamp, C. H. Racine, V. E. Romanovsky, R. S. Stone, D. A. Stow, M. Sturm, C. E. Tweedie, G. L. Vourlitis, M. D. Walker, D. A. Walker, P. J. WebBer, J. M. Welker, K. S. Winker, AND K. YoshikaWA. 2005. Evidence and implications of recent climate change in northern Alaska and other arctic regions. Climatic Change 72:251-298.

IUCN Standards AND Petitions SubCommittee [ONLINE]. 2011. Guidelines for using the IUCN Red List categories and criteria, version 9.0. Prepared by the Standards and Petitions Subcommittee. <http://www. iucn.org/documents/RedListGuidelines.pdf $>$ (15 October 2011).

Johnson, M., J. R. Conklin, B. L. Johnson, B. J. McCafferi, S. M. HAig, AND J. R. WALTERS. 2009. Behavior and reproductive success of Rock Sandpipers breeding on the Yukon-Kuskokwim River delta, Alaska. Wilson Journal of Ornithology 121:328-337.

KLEIN, D. R. 1968. The introduction, increase, and crash of reindeer on St. Matthew Island. Journal of Wildlife Management 32:350-367.

KLEIN, D. R. 1987. Vegetation recovery patterns following overgrazing by reindeer on St. Matthew Island. Journal of Range Management 40:336-338.

LANDE, R. 1993. Risks of population extinction from demographic and environmental stochasticity and random catastrophes. American Naturalist 142:911-927.

MARQUES, F. F. C., AND S. T. BUCKLAND. 2003. Incorporating covariates into standard line transect analyses. Biometrics 59:924-935.

MatsuoKa, S. M., AND J. A. Johnson. 2008. Using a multimodel approach to estimate the population size of McKay's Buntings. Condor 110:371-376.

Miller, E. H., W. W. H. Gunn, AND B. N. Veprintsev. 1988. Breeding vocalizations of Baird's Sandpiper Calidris bairdii and related species, with remarks on phylogeny and adaptation. Ornis Scandinavica 19:257-267.

Morrison, R. I. G., B. J. McCaffery, R. E. Gill, S. K. Skagen, S. L. Jones, G. W. Page, C. L. Gratto-Trevor, and B. A. ANDRES. 2006. Population estimates of North American shorebirds, 2006. Wader Study Group Bulletin 111:67-85.

Nebel, S., AND B. J. McCAFFERY. 2003. Vocalization activity of breeding shorebirds: documentation of its seasonal decline and applications for breeding bird surveys. Canadian Journal of Zoology 81:1702-1708.

Osgood, W. H., E. A. Preble, And G. H. Parker. 1915. The fur seals and other life of the Pribilof Islands, Alaska, in 1914. Bulletin of the Bureau of Fisheries 34

Pimm, S. L., H. L. Jones, And J. Diamond. 1988. On the risk of extinction. American Naturalist 132:757-785.

Preble, E. A., And W. L. McAtee. 1923. Birds and mammals of the Pribilof Islands, Alaska. North American Fauna 46.

Pruett, C. L., AND K. WinKer. 2005. Biological impacts of climatic change on a Beringian endemic: cryptic refugia in the establishment and differentiation of the Rock Sandpiper (Calidris ptilocnemis). Climatic Change 68:219-240.

RAUSCH, R. L., AND V. R. RAUSCH. 1968. On the biology and systematic position of Microtus abbreviatus Miller, a vole endemic to the St. Matthew Islands, Bering Sea. Zeitschrift für Säugetierkunde 33:65-99.

Reed, D. H., and R. Frankham. 2003. Correlation between fitness and genetic diversity. Conservation Biology 17:230-237.

Reed, D. H., J. J. O'Grady, B. W. Brook, J. D. Ballou, and R. FRANKHAM. 2003. Estimates of minimum viable population sizes for vertebrates and factors influencing those estimates. Biological Conservation 113:23-34

RidgWAY, R. 1919. The birds of North and Middle America, part 8. Bulletin of the U.S. National Museum 50.

Rupp, T. S., F. S. Chapin III, AND A. M. STARFIELD. 2000. Response of subarctic vegetation to transient climatic change on the Seward Peninsula in north-west Alaska. Global Change Biology 6:541-555.

SHAFFER, M. L. 1981. Minimum population sizes for species conservation. BioScience 31:131-134.

Sturm, M., C. Racine, AND K. TAPE. 2001. Increasing shrub abundance in the Arctic. Nature 411:546-547.

Swanson, J. D., AND M. H. W. BARKER. 1992. Assessment of Alaska reindeer populations and range conditions. Rangifer 12:33-43.

Talbot, S. S., S. L. Talbot, J. W. Thomson, and W. B. Schofield. 2001. Lichens from St. Matthew and St. Paul islands, Bering Sea, Alaska. Bryologist 104:47-58.

TAPE, K., M. STURM, AND C. RACINE. 2006. The evidence for shrub expansion in northern Alaska and the pan-Arctic. Global Change Biology 12:686-702.

Thomas, L., S. T. Buckland, E. Rexstad, J. L. Laake, S. StrindBerg, S. L. Hedley, J. R. B. Bishop, T. A. Marques, and K. P. BurnhaM. 2010. Distance software: design and analysis of distance sampling surveys for estimating population size. Journal of Applied Ecology 47:5-14.

THOMPson, W. L. 2002. Towards reliable bird surveys: accounting for individuals present but not detected. Auk 119:18-25.

Tomkovich, P. S. 1994. Site fidelity and spatial structure of population in the Rock Sandpiper Calidris ptilocnemis and Dunlin Calidris alpina on Chukotsky Peninsula. Russian Journal of Ornithology 3:13-30. [In Russian.]

U.S. Census Bureau [online]. 2011. U.S. Census Bureau 2009 population estimates. <http://www.census.gov/> (15 October 2011).

WRIGHT, J. M. 1979. Reindeer grazing in relation to bird nesting on the northern Seward Peninsula. M.Sc. thesis, University of Alaska, Fairbanks, AK. 